\title{
Cosmetic contact lenses: beauty can be blinding
}

Nanthini Selvaraja1,2, Raja Norliza Raja Omar², Anhar Hafiz bin Silim², Ahmad Tajudin Liza-Sharmini ${ }^{1}$

${ }^{1}$ Department of Ophthalmology and Visual Sciences, School of Medical Sciences, Health Campus, Universiti Sains Malaysia, Kubang Kerian, Kelantan, Malaysia. ${ }^{2}$ Department of Ophthalmology, Hospital Melaka, Jalan Mufti Haji Khalil, Melaka, Malaysia

\section{Abstract}

Background: Although cosmetic contact lenses are ideally indicated for patients with corneal and iris abnormalities, they are currently fashionable among the younger generation of emmetropes to enhance their physical appearance. Cosmetic contact lens wearers carry a greater risk of microbial keratitis, even more so with counterfeit ones.

Case presentation: Here, we report two cases of counterfeit cosmetic contact lens wearers with Acanthamoeba keratitis (AK) who were misdiagnosed as herpes simplex virus (HSV) keratitis.

Conclusion: AK is a sight-threatening complication among contact lens wearers. Since clinically AK may masquerade as HSV, early diagnosis of AK is often delayed. As both microorganisms can mimic each other, determining the co-existence of both infections can be challenging. Delay in initiating proper treatment can lead to blinding complications.

Keywords: Acanthamoeba keratitis, cosmetic contact lens, herpes simplex masquerade syndrome, radial keratoneuritis

Correspondence: Professor Dr Liza Sharmini Ahmad Tajudin, MBBS (Mal), MMed (Ophthal) (USM), PhD (UK), AM (Mal), Department of Ophthalmology and Visual Sciences, School of Medical Sciences, Health Campus, Universiti Sains Malaysia, 16150, Kubang Kerian, Kelantan, Malaysia.

E-mail: liza@usm.my 


\section{Kanta sentuh kosmetik: kecantikan yang boleh menbutakan}

\section{Abstrak}

Latar belakang: Secara idealnya, indikasi pemakaian kanta sentuh kosmetik adalah untuk pesakit yang mempunyai kornea atau iris mata abnormal. Namun, ianya kerap dipakai oleh generasi remaja emetrop untuk mempertingkatkan keterampilan diri. Pengguna kanta sentuh kosmetik berisiko tertinggi untuk jangkitan keratitis, dimana kesannya lebih teruk jika menggunakan kanta sentuh kosmetik tiruan.

Pembentangan kes: Dua (2) kes pemakai kanta sentuh kosmetik tiruan dengan Acanthamoeba keratitis (AK) yang telah di salah diagnos sebagai HSV keratitis di peringkat awal, dilaporkan.

Kesimpulan: Acanthamoeba keratitis adalah kompikasi yang mengancam penglihatan di kalangan pengguna kanta sentuh. AK selalunya sukar dikesan diperingkat awal kerana mudah menyamar sebagai herpes simplex virus, secara klinikal. Oleh itu, pengenalpastian keujudan mikroorganisma tersebut adalah mencabar. Kelewatan dalam memulakan rawatan boleh menyebabkan komplikasi terhadap penglihatan.

Kata kunci: Acanthamoeba keratitis, kanta sentuh kosmetik, keratoneuritis radial, sindrom penyamar herpes simplex

\section{Introduction}

Contact lenses are often used to replace spectacles, which are perceived as unattractive, particularly among younger age groups and females with refractive errors. ${ }^{1}$ However, with the influence of social media, cosmetic contact lenses have lately gained popularity among emmetropes. Cosmetic contact lenses are often used to change the colour of the iris as well as the shape and size of the cornea without any surgical intervention. Despite regulation in many countries, counterfeit cosmetic contact lenses are widespread, especially in Southeast Asia including Malaysia. ${ }^{2}$ The complications of cosmetic contact lenses are similar to those for refractive correction. ${ }^{1}$

Corneal infection is the greatest sight-threatening complication related to contact lenses. Contact lenses have been identified as a risk factor for Acanthamoeba keratitis (AK) in 95\% of reported cases. ${ }^{3}$ However, diagnosis of AK is often delayed and challenging. Here, we report two case cases of counterfeit cosmetic contact lens wearers who were misdiagnosed with herpes simplex masquerade syndrome. 


\section{Case presentation}

\section{Case 1}

An emmetropic 19-year-old woman who regularly wore cosmetic contact lenses, presented with painful bilateral red eye, photophobia, tearing, and decreased visual acuity for a week. She bought her cosmetic contact lenses and lens solutions from various unauthorized sellers including through online shopping for the past 4 years. She also occasionally bought the extended wear contact lenses. She claimed to practice good contact lens hygiene techniques, but occasionally slept while wearing the contact lenses.

On examination, her visual acuity was $6 / 36$ bilaterally. Anterior segment examination showed multiple epithelial pseudodendrites and epithelial erosion in both eyes. Bilateral corneal sensation was intact. Based on the clinical findings, she was treated as herpes simplex virus (HSV) keratitis and prescribed ointment acyclovir with oral analgesia. However, after a week of treatment, there was no improvement in her visual acuity. Subsequently, she developed bilateral keratoneuritis with multifocal stromal infiltrates and ring infiltrates. There was also the early formation of stromal abscess measuring $2 \mathrm{~mm}$ (vertical) x $1.6 \mathrm{~mm}$ (height) in the left eye but without the presence of cells. Bilateral corneal sensation was reduced. Both fundi were unremarkable. Corneal scraping found double wall Acanthamoeba cysts on haematoxylin and eosin (H\&E) staining.

The diagnosis was revised as bilateral AK based on clinical findings and microbiological evidence. She was treated with topical chlorhexidine $0.02 \%$ and brolene $0.1 \%$ hourly for both eyes. A week after initiation of intensive treatment, pseudodendrite and ring infiltrate density lessened; visual acuity in the right eye improved to $6 / 24$ but remained $6 / 36$ in the left eye. After 3 months of treatment, visual acuity for both eyes improved to $6 / 18$. The patient is, at the time of writing, still undergoing treatment with gradual tapering of medication.

\section{Case 2}

A 35-year-old schoolteacher and regular cosmetic contact lens wearer presented with reduced vision and painless bilateral red eye for a week. She was emmetropic but had been wearing cosmetic contact lenses for the past 5 years. She preferred extended wear contact lenses and often slept without removing them. She also often washed her face with tap water while wearing her contact lenses. She stopped wearing her contact lenses for a week after having eye redness related to her complaint.

On examination, visual acuity was $6 / 24$ bilaterally. Anterior segment examination showed a peripheral dendritic lesion with stromal infiltrates in both eyes. There was diminished corneal sensation on both eyes. She was treated for HSV keratitis and started on ointment acyclovir and fluorometholone eye drops. One week later during her follow-up visit, her symptoms improved but there was 


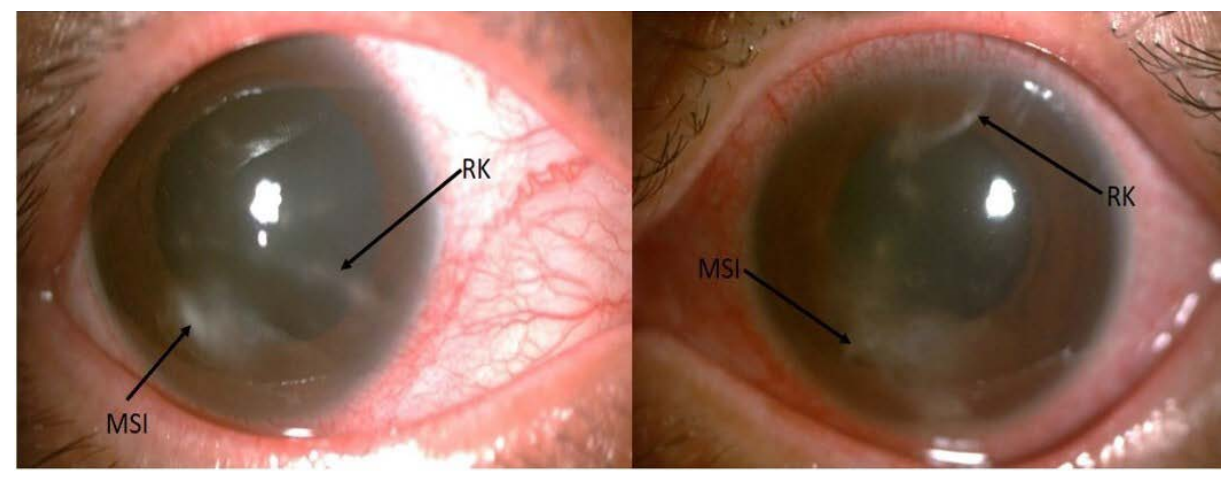

Fig. 1. Anterior segment photograph of Case 2 showing the presence of radial keratoneuritis (labelled RK) and stromal infiltrates (labelled MSI).

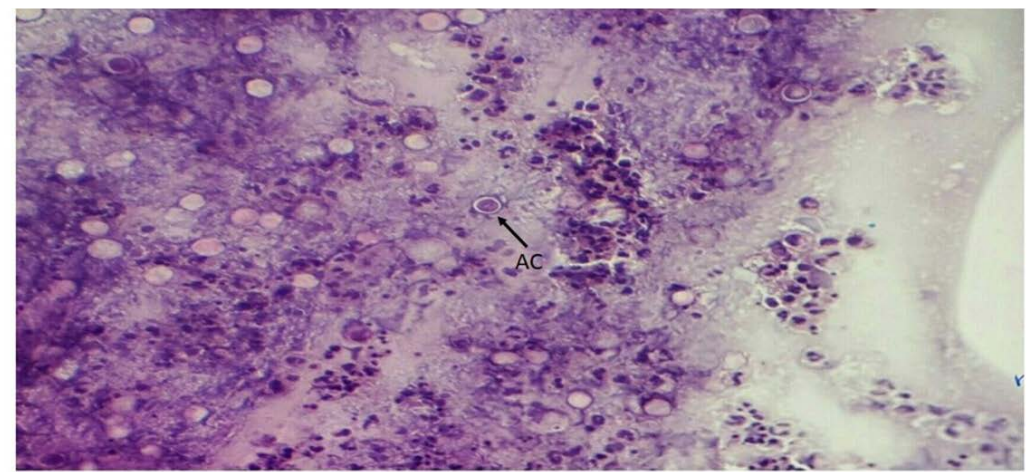

Fig. 2. Histopathological examination slide showing the presence of Acanthamoeba cyst (labelled AC) from the corneal scraping.

perineural infiltrates in both eyes (Fig. 1). Corneal scraping found double wall Acanthamoeba cysts on H\&E staining (Fig. 2).

Diagnosis was revised as bilateral AK and the patient was started on topical chlorhexidine $0.02 \%$ and brolene $0.1 \%$ hourly for both eyes. There was clinical improvement with reduced density of perineural infiltrates after a week of intensive treatment. Visual acuity in the right eye improved to $6 / 12$ and to $6 / 18$ in the left eye. After 3 months of initial treatment, the perineural infiltrates resolved but her vision did not improve further. At the time of writing, the patient is still on treatment and long-term follow-up. 


\section{Discussion}

Emmetropic cosmetic contact lens wearers may perceive they do not need specialist fitting or advice on adequate use and care of the lenses due to aesthetic and often infrequent usage. This perhaps increases the risk of microbial keratitis, a sight-threatening complication. ${ }^{2}$ Increased roughness and the presence of dye in these cosmetic contact lenses increase the risk of trauma and infection. ${ }^{1}$ Due to infrequent use, long exposure in contact lens solution may incubate microorganisms. AK has been reported in cosmetic contact lens wearers more often than in conservative contact lens wearers. ${ }^{9}$

Epithelial manifestations of AK include pseudodendrites, epithelial microerosions, and subepithelial microcysts. Pseudodendritic lesions in AK differ from those of HSV keratitis, where these do not have round spot-like widenings at the ending of the epithelial erosions. ${ }^{4}$ The stromal manifestations include multifocal stromal infiltrates, Wessely immune rings, and radial keratoneuritis.

Both cases in this report demonstrated the presence of dendritic lesions with epithelial involvement (Case 1) and stromal involvement (Case 2). Epithelial involvement is usually suggestive of active replication of the virus, while stromal infiltration is associated with immune-mediated response to a non-replicating virus. ${ }^{6}$ Ring infiltrates may be present in AK and HSV keratitis. Stromal oedema and infiltrates can occur in AK, which masquerade as a disciform lesion in HSV keratitis (Case 2). Decreased corneal sensitivity is another common sign for both corneal infections. ${ }^{7}$ Thus, they can both mimic each other, which further delays management. ${ }^{8}$

HSV may reduce the healing ability and defence mechanism of the cornea, leading to an immunocompromised state. Thus, potential coexisting infections of Acanthamoeba and other organisms is possible. ${ }^{5}$ Corneal sensitivity to mechanical stimuli is associated with the number of recurrences in HSV keratitis and part of the presenting signs of AK. ${ }^{4}$ The absence of corneal sensation in Case 2 may further predispose to secondary infection and impaired healing process. However, no viral culture or polymerase chain reaction were done to confirm HSV. In addition, confocal microscopy has the potential to aid in differentiating HSV keratitis from AK. ${ }^{7}$

Both cases were treated initially as HSV keratitis based solely on clinical findings. Even though both cases appeared to improve, the pathognomonic sign of AK, a radial pattern of perineural infiltrates developed subsequently. ${ }^{8}$ The cases were then treated as AK based on the clinical and microbiological evidence. General practitioners are advised to regard with a high index of suspicion corneal infections in patients with reduced vision and a history of contact lens use, particularly cosmetic ones. Although there was a slight delay in management, the infection was contained in both cases. However, both patients unfortunately developed visual impairment as the sequelae. It is thus important to raise awareness among the public of the danger of beauty to vision. Indeed, beauty is in the eye of the beholder. 


\section{Declarations}

\section{Consent for publication}

The corresponding author declares to have received informed, sufficient, and express consent from the patients for the use of their clinical data and images in this article.

\section{Competing interests}

None to declare.

\section{Funding}

None to declare.

\section{Acknowledgements}

None to declare.

\section{References}

1. Lim CHL, Stapleton F, Mehta JS. A review of cosmetic contact lens infections. Eye (Lond). 2019;33(1):78-86. http://doi.org/10.1038/s41433-018-0257-2. Epub 2018 Nov 1. PMID: 30385879; PMCID: PMC6328606.

2. Fleiszig SM, Evans DJ. Pathogenesis of contact lens-associated microbial keratitis. Optom Vis Sci. 2010;87(4):225-32. http://doi.org/10.1097/OPX.0b013e3181d408ee. PMID: 20190671; PMCID: PMC4379041.

3. Ibrahim YW, Boase DL, Cree IA. How Could Contact Lens Wearers Be at Risk of Acanthamoeba Infection? A Review. J Optom. 2009;2(2):60-66. http://doi.org/10.3921/joptom.2009.60.

4. Mathers WD, Goldberg MA, Sutphin JE, Ditkoff JW, Folberg R. Coexistent Acanthamoeba keratitis and herpetic keratitis. Arch Ophthalmol. 1997;115(6):714-8. http://doi.org/10.1001/ archopht.1997.01100150716002. PMID: 9194720.

5. Cheng KH, Leung SL, Hoekman HW, et al. Incidence of contact-lens-associated microbial keratitis and its related morbidity. Lancet. 1999 Jul 17;354(9174):181-5. http://doi.org/10.1016/S01406736(98)09385-4. PMID: 10421298.

6. Johns KJ, O'Day DM, Head WS, Neff RJ, Elliott JH. Herpes simplex masquerade syndrome: acanthamoeba keratitis. Curr Eye Res. 1987;6(1):207-12. http://doi.org/10.3109/02713688709020092. PMID: 3829702

7. Heydar Siatiri MD, Asadi-Amoli F. Herpes Simplex Masquerade Syndrome: Acanthamoeba Necrotizing Stromal Keratitis. Iranian Journal of Ophthalmology. 2006;19(2):57-9.

8. Panwar P, Sharma K. Acanthamoeba keratitis-a diagnostic dilemma: a case report. Adv Ophthalmol Vis Syst. 2018;8(1):52-53. http://doi.org/10.15406/aovs.2018.08.00268 
9. Moore MB, McCulley JP, Luckenbach M, et al. Acanthamoeba keratitis associated with soft contact lenses. Am J Ophthalmol. 1985;100(3):396-403. http://doi.org/10.1016/0002-9394(85)90500-8. PMID: 3898851. 